О. В. Третьяков ${ }^{1}$, Б. К. Гармаш ${ }^{1}$, Б. Д. Халмурадов ${ }^{2}$, Є. С. Білецька ${ }^{1}$

${ }^{1}$ Український державний університет залізничного транспорту, Харків, Україна

${ }^{2}$ Національний авіаційний університет, Київ, Україна

\title{
РИЗИК-ОРІЄНТОВАНИЙ ПІДХІД ДО ВИЗНАЧЕННЯ УМОВ ПРАЦІ ОКРЕМИХ КАТЕГОРІЙ ПРАЦІВНИКІВ ТРАНСПОРТНОӤ ГАЛУЗІ
}

\begin{abstract}
Анотація. В даній статті розглянуті питання щодо аналізу принципів, методів і критеріїв оцінки ризику. Дано визначення поняттю професійного ризику, як нанесення шкоди здоров'ю людини умовами професійної діяльності. Встановлено, що основним напрямком підвищення безпеки умов праці є системний підхід, заснований на аналізі та оцінці ризиків, обумовлених специфікою процесів у транспортній галузі. Виявлено об'єктивні закономірності виникнення небезпек у професійній діяльності працівників залізничного транспорту. Сучасна тенденція глобалізації світової економіки та регіональної інтеграції підвищила необхідність у співпраці між різними країнами, оскільки об'єктивно існують спільні цілі і підходи в сфері промислової безпеки та гігієни праці, необхідність взаємодії між професійною безпекою і змінами в навколишньому середовищі, а також між гігієною і продуктивністю праці. Метою такої системної політики є попередження нещасних випадків і професійних захворювань працівників в результаті виникнення небезпечних ситуацій і аварій на транспорті. Отримано єдиний підхід до розрахунку виробничого ризику в залежності від параметрів робочої зони з урахуванням часу перебування працюючих у зоні дії небезпечних факторів, який не потребує введення множини шкал для характеристики якості середовища. На основі алгоритму перетворення параметрів середовища в показник виробничого ризику був проведений аналіз карт умов праці за результатами атестації робочих місць регіональної філії «Південна залізниця» ПАТ «Українська залізниця». Отримані показники інтегрального ризику свідчать про суб`єктивність оцінки фактичних умов та характеру праці згідно існуючого законодавства. Виявлено протиріччя українського законодавства світовим нормам щодо охорони здоров я та безпеки праці для створення контрольованих умов, які мінімізують можливі наслідки шкідливих та небезпечних факторів виробничого середовища та трудового процесу. Запропоновано метод визначення рівня небезпеки для працівників у робочій зоні за умов сумісної дії шкідливих факторів різних класів, який передбачає, що отримані на основі ризик-орієнтованого підходу залежності можна застосовувати для атестації робочих місць, при визначенні пріоритету щодо заходів з охорони праці з урахуванням рівня виробничого і професійного ризиків.
\end{abstract}

Ключов і слова: транспорт, професійний ризик, виробничий ризик, шкідливий фактор, небезпечний фактор, професійна безпека та здоров`я, охорона праці, гігієнічний норматив.

\section{Вступ}

При інтеграції в світове співтовариство, розробка і реалізація основних положень гармонізації принципів, методів і критеріїв оцінки ризику для здоров'я працівників 3 міжнародними підходами $є$ необхідною умовою забезпечення соціально-економічного розвитку держави [1]. Це дозволить перейти до гармонізації гігієнічних нормативів, розроблених на базі критеріїв ризику для здоров'я, України та країн Європейського Союзу. В документах Європейської комісії підкреслюється, що науково обгрунтована оцінка ризику відіграє виняткову роль при підготовці та удосконаленні законодавства в сфері захисту прав громадян і особливо їх здоров'я [3, 4]. Окремо виділяється положення про те, що проведення оцінки ризику відповідно до міжнародновизнаних процедур дає підставу для захисту власних прав громадян у судовому порядку [2].

Охорона праці має бути одним 3 найважливіших завдань соціально-економічної політики держави, а також окремого підприємства або організації. Заходи щодо поліпшення умов праці для попередження виробничого травматизму i професійних захворювань в умовах сучасного виробництва виявились неефективними. Необхідне здійснення комплексного аналізу умов праці, а також створення підсистеми управління безпекою праці на основі проектних підходів в загальній системі керування виробництвом [6]. Управління проектами з охорони праці включає до себе планування, прийняття рішень та реалізацію заходів, які спрямовані на забезпечення безпеки, збереження здоров'я і працездатності людини безпосередньо в процесі праці [7]. Отже, маємо в наявності множину факторів виробничого середовища, які $є$ передумовою щодо створення задачі для визначення інтегрального показника рівня небезпеки для працівників.

Аналіз останніх досліджень і публікацій. Поняття «ризик» не має однозначного визначення. Відсутня загальновизнана система термінів у оцінюванні ризику. Найчастіше застосовують поняття «небезпека» $\mathrm{i}$ «ризик». Джерелом небезпеки і ризику для здоров я людини можуть бути суспільство, навколишнє середовище і техніка разом або кожний із цих факторів окремо, тобто можна відокремити джерела небезпеки і ризику природного, соціального або природно-соціального розвитку [3].

За ступенем припустимості ризик буває надмірним, гранично допустимим, таким, яким можна знехтувати [4]. Як свідчить практика, досягти абсолютної безпеки - нульового ризику, неможливо. На теперішній час найбільше поширення отримала концепція допустимого (прийнятного) ризику. Суть даної концепції полягає у створенні такого рівня безпеки, який суспільство може прийняти, тобто економічно виправдати. Допустимий ризик визначається як такий, що реально існує у певному виді діяльності, і який не утримує обізнану людину від дій, пов язаних із імовірною небезпекою. Таким 
чином, можна визначити допустимий ризик, як компроміс між рівнем безпеки та реалізацією політичних, соціальних, економічних і технічних можливостей держави.

Система управління охороною праці, політика підприємства в галузі охорони праці представляє собою складний вид проектно-орієнтованої діяльності в системі «людина - машина - робоча зона». Ознаками такої діяльність можуть бути мета, тобто рівень виробничої безпеки, і певні терміни виконання (початок і закінчення), а також встановлені фінансові, матеріальні та трудові ресурси; процеси, заходи та операції, які необхідні для досягнення мети [11].

Але проекти 3 охорони праці мають свої відмінності. Безпека, а це цільова функція проекту, по суті, не пов'язана з прибутком від виготовлення та реалізації продукту або надання послуги. Спосіб утворення небезпечних факторів та властивості чинників шкідливого впливу $\epsilon$ унікальним для окремого виробничого середовища або трудового процесу. Щодо умов реалізації проектів з охорони праці, то вони, спрямовані на забезпечення безпеки працівників у процесі праці.

Теоретичною базою щодо формування концепції безпеки в організаційно-технічних системах $є$ аксіома про потенційну небезпеку, закон ВебераФехнера, принцип мінімуму Лібіха, закон толерантності Шелфорда, принцип Фармера [8]. Для визначення ризику скорочення тривалості життя при дії шкідливих факторів у робочій зоні підприємств беремо за основу закон Вебера-Фехнера [8]. Інші підходи оцінки ризику розглянуті в роботах $[10,11-$ 13]. Рівень впливу факторів середовища на стан людей можна визначити за допомогою даних у формі залежності «доза - ефект» [10]. В охороні праці взагалі деякий продукт або послуга, що характеризуються ціною і мірою ризику, і $є$ результатом проектів.

В основному, оцінка ризику проводиться імовірнісною характеристикою і $є$ безрозмірною величиною від 0 до 1. Але можливе використання і частоти реалізації ризику, яка є числом випадків можливого прояву небезпеки за певний період часу. Якщо, наприклад, число випадків можливого прояву небезпеки на рік, тоді одиниці виміру ризику можуть бути такими - [1/рік] або[людей/рік].

На даний час, існують дві давно сформовані точки зору на ризик. Теоретичний ризик $є$ першою точкою зору на ризик, яка базується на наукових i технічних оцінках. Відповідно, іншою точкою зору на ризик, яка залежить від людського сприйняття ризику, є так званий ефективний ризик [11].

Визначення мети та завдання дослідження. Розробка методу визначення рівня небезпеки для працівників у робочій зоні за умов сумісної дії шкідливих факторів різних класів.

\section{Основний матеріал}

Небезпеки за своїм проявом мають потенційний, тобто скритий характер. Причинами $є$ умови, при яких реалізуються потенційні небезпеки. Зага- лом, вони характеризують сукупність обставин, через які проявляються небезпеки, а отже викликають ті чи інші небажані наслідки або наносять шкоду. За формою шкода або небажані наслідків мають різноманітний прояв. Це травми різної важкості, захворювання, які визначаються сучасними методами, шкода довкіллю тощо. Отже, послідовність «небезпека - причини - небажанні наслідки» являє собою логічний процес розвитку, що реалізує потенційну небезпеку у реальні наслідки. «Життєдіяльність людини потенційно небезпечна» - це аксіома, яка ілюструє наявність потенційних небезпек.

Об'єктом аналізу небезпек є система «людина машина - навколишнє середовище», де об'єднуються технічні об'єкти, люди і навколишнє середовище, які взаємодіють між собою. Під потенційною небезпекою або шкідливістю виробничих процесів мають на увазі наявність небезпечних і шкідливих факторів, які діючи на людину можуть призвести до виробничої травми або професійного захворювання.

Існуючі методи визначення рівня небезпеки від сумісної дії шкідливих факторів у виробничих умовах засновані на принципі мінімуму Лібіха, але його недоліком є урахування факторів, що мають максимальний вплив [8,9]. Але існують інші фактори, які не мають перевищення допустимих нормативів, хоча теж суттєво впливають на стан здоров'я працівників. Таке протиріччя можна усунути засобом впровадження ймовірнісних оцінок рівня небезпеки виробничого середовища. Пропонується визначення рівня небезпеки у робочій зоні за допомогою функції ризику, що дозволить автоматизувати процес атестації робочих місць [10].

Формою вираження теоретичного ризику є статистичний показник, зведений до ймовірності деякої небажаної події. Надалі імовірність такої події, деяка оцінка очікуваної шкоди об'єднуються в один показник, а отже, комбінується набір ймовірностей ризику і шкоди або винагороди. В статистичній теорії прийняття рішень, функцію ризику оцінки $\delta(x)$ для параметра $\theta$, що обчислена при деяких спостережуваних параметрах $x$, визначають як математичне очікування функції втрат $L(\theta, \delta(x))$ :

$$
R(\theta)=\int L(\theta, \delta(x)) \cdot f(x \mid \theta) d x
$$

де $L(\theta, \delta(x))$ - функція втрат від параметра оцінки $\theta$ і значення оцінки $\delta(\mathrm{x})$;

$f(x \mid \theta)$ - ймовірність небажаної події.

На практиці, як правило, використовують окремі форми виразу (1). По суті, їх метою є істотне спрощення залежності, при врахуванні конкретних умов виконання оцінки ризику. Таким чином, імовірність небажаної події можна визначити через часту реалізації небезпек:

$$
P=f(x \mid \theta)=\frac{N(t)}{Q(x)},
$$

де $N(t)$ - число небажаних подій за час $t ; Q(x)$ - загальне число подій у системі. 
Оцінки ризику у робочій зоні за умов впливу факторів середовища виконуються, як правило, із припущенням, що рівень забруднення відомий [11]. Це означатиме, що подія забруднення вже відбулась, тобто $P=1$.

Зазвичай, для функції втрат $L(\theta, \delta(x))$ приймають деяку вартісну міру одиниці ризику, що характеризує наслідки якої-небудь події. 3 точки зору роботодавця вартісна міра ризику прийматиметься такою, що дорівнює розміру п'ятирічного заробітку працівника, згідно до законодавства. Встановлення подібної вартісної оцінки може бути доречним і для інших рівнів тяжкості небажаних подій.

Відповідно до закону Вебера-Фехнера, при забрудненні атмосферного повітря в загальному випадку, має місце існування деякої функціональної залежності між рівнем забруднення, відчуттям і ризиком:

$$
r=\frac{1}{k} \cdot \lg \frac{C}{C_{0}},
$$

де $r$ - рівень ризику; $C$ - концентрація шкідливих речовин в повітрі, мг $/ \mathrm{M}^{3} ; k-$ коефіцієнт пропорційності; $C_{0}-$ найменша концентрація, при якій відчувається дія.

Якщо взяти за основу нормативні показники, які визначаються експериментально для кожної окремої речовини, можна встановити дві закріплені точки залежності (3). Виконаємо заміну $1 / k$ на $\lambda$ для спрощення перетворень:

$$
\left\{\begin{array}{l}
1 \cdot 10^{-6}=\lambda \cdot \lg \left(\text { ГДК Сд } / C_{0}\right) \\
0,5=\lambda \cdot \lg \left(Л \kappa_{50} / C_{0}\right) \\
r=\lambda \cdot \lg \left(C / C_{0}\right) .
\end{array}\right.
$$

Розв'язання системи рівнянь (4) для концентрацій забруднюючих речовин, що перевищують ГДК сд матиме такий вигляд:

$$
\begin{aligned}
& \lambda=\frac{0,5-1 \cdot 10^{-6}}{\lg \frac{Л K_{50}}{\Gamma Д K_{C Д}}},
\end{aligned}
$$

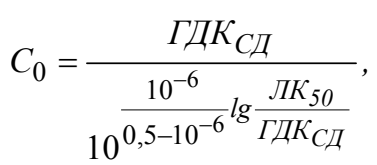

$$
\begin{aligned}
& r=\left(0,5-10^{-6}\right) \cdot\left(\frac{\lg \frac{C}{\Gamma Д К_{C Д}}}{\lg \frac{\sqrt{Л K_{50}}}{\Gamma Д K_{C Д}}}+\frac{10^{-6}}{0,5-10^{-6}}\right) . \\
& r=\frac{0,5-1 \cdot 10^{-6}}{\lg \frac{Л K_{50}}{\Gamma Д \kappa_{C д}}} \lg \frac{C}{\Gamma Д \kappa_{C д}}+1 \cdot 10^{-6}
\end{aligned}
$$

Підтвердження тому, що наслідки дії хімічних факторів на людину в процесі іiі трудової діяльності, відповідають закону Вебера-Фехнера, знайдено у рівняннях (5) - (7). Відмінність (6) від класичного виразу для залежності Вебера-Фехнера полягає в тому, що (6) містить вільний член $10^{-6}$, який характеризує верхню границю дії. Іншою відмінністю виразу (6) $є$ введення нормування ризику в координатах ЛК 50 і ГДК кута нахилу лінійної залежності ризику від логарифма нормованого відносно ГДК дд діючої речовини. Загалом, отримана залежність (6) є узагальненням закону Вебера-Фехнера в частині дії хімічних речовин на організм людини.

Аналогічним чином визначаємо залежності ризику для шуму, іонізуючого випромінювання та електромагнітних коливань для розрахування потенційного ризику при дії різнорідних факторів (табл. 1).

При оцінці рівня небезпеки основною дією $\epsilon$ перетворення інформації про декотру властивість параметрів середовища у показники ризику. Але на цій стадії виникає складність, яка пов'язана $з$ тим, що попередні дослідження характеру дії шкідливих речовин і інших факторів проводилися без урахування взаємного впливу факторів. Тому питання про перетворення «доза - ефект», має вирішуватися, виходячи 3 наявних експериментальних даних табл. 1. Таким чином, вказане перетворення може здійснюватися відносно кожної елементарної властивості з подальшим зведенням окремих показників до єдиного критерію якості системи в цілому. Але у загальному випадку, розглядаючи характер причинно-наслідкового зв'язку в послідовності «дія - відчуття - реакція», це не має принципового значення.

Далі розглянемо алгоритм перетворення параметрів середовища в показник виробничого ризику. Вирази для розрахунку потенційного ризику при дії різнорідних факторів приведені в табл. 2. Вибір коефіцієнтів $b$ відбувається для кожної діючої речовини, аналогічно коефіцієнт $k$ - для відповідного інтервалу частот електромагнітних коливань.

Відповідно, за умов, при яких значення фактора має менше значення від прийнятного нормативного, величину ризику можна розрахувати із припущенням, що зміна його величини від значення фактора є лінійною:

$$
r_{i}=\alpha \cdot F
$$

де $\alpha=10^{-6} / \Gamma Д Р ; ~ F-$ величина фактора, $F<$ ГДР.

Надалі, проводиться розрахунок сумарного ризику в такій послідовності. Насамперед розраховуються значення величини річного ризику для кожного фактора $r_{i}$, а потім обчислюється величина інтегрального ризику:

$$
R=1-\prod_{1=1}^{n}\left(1-r_{i}\right),
$$

Отже, все вищенаведене свідчить про отримання єдиного підходу до розрахунку оцінки параметрів робочої зони, який не потребує введення множини шкал для характеристики якості середовища. Загалом, використання оцінки у вигляді відношення двох величин еквівалентно переходу від інтенсивності до екстенсивної характеристики впливу. 
Таблиия1 - Розрахунок потенційного ризику при дії різнорідних факторів

\begin{tabular}{|c|c|c|c|c|}
\hline $\begin{array}{c}\text { Параметри якості } \\
\text { середовища }\end{array}$ & $\begin{array}{c}\text { Одиниці } \\
\text { вимірювання }\end{array}$ & $\begin{array}{l}\text { Норматив прийн- } \\
\text { ятного рівня }\end{array}$ & $\begin{array}{l}\text { Надмірний } \\
\text { рівень }\end{array}$ & $\begin{array}{c}\text { Формула для розрахунку } \\
\text { ризику }\end{array}$ \\
\hline Хімічні речовини & $\mathrm{M \Gamma} / \mathrm{M}^{3}$ & $\begin{array}{c}\text { ГДК } \text { сд } \text { залежить } \\
\text { від речовини } \\
\end{array}$ & ЛК ${ }_{50}$ & $r=10^{-6}+b \cdot \lg (C / Г Д К)$ \\
\hline Шум & дБА & ГДР & 130 дБА & $r=10^{-6}+0,038 \cdot \lg \left(I / I_{0}\right)$ \\
\hline $\begin{array}{c}\text { Іонізуюче } \\
\text { випромінювання }\end{array}$ & м3в рік-1 & $\begin{array}{l}\text { Ліміт дози, } \\
\text { ГДР=20 }\end{array}$ & $>50$ & $r=10^{-6}+0,358 \cdot \lg \frac{D_{E}}{\Gamma Д Р}$ \\
\hline $\begin{array}{c}\text { Електромагнітні } \\
\text { коливання } \\
\end{array}$ & $\mathrm{BT} / \mathrm{m}^{2}$ & $\begin{array}{c}\text { ГДЕЕ, залежить } \\
\text { від частоти }\end{array}$ & $>500$ & $r=10^{-6}+k \cdot \lg (E / Г Д Е E)$ \\
\hline
\end{tabular}

Таблиця 2 - Розрахунок оцінки параметрів робочої зони

\begin{tabular}{|c|c|c|c|c|c|c|c|}
\hline $\begin{array}{l}\text { № } \\
\text { 3/II }\end{array}$ & $\begin{array}{l}\text { Робоче місце, професія, } \\
\text { цех (дільниця, відділ) }\end{array}$ & $\begin{array}{l}\text { Клас } \\
\text { умов } \\
\text { праці } \\
\end{array}$ & $\begin{array}{c}\text { Фактори виробни- } \\
\text { чого середовища i } \\
\text { трудового процесу } \\
\end{array}$ & $\begin{array}{c}\text { Нормативне } \\
\text { значення } \\
\text { (ГДК), (ГДР) } \\
\end{array}$ & $\begin{array}{c}\text { Фактич- } \\
\text { не зна- } \\
\text { чення } \\
\end{array}$ & $\begin{array}{c}\text { Потенцій- } \\
\text { ний ризик, } \\
r_{i}, \\
\end{array}$ & $\begin{array}{c}\text { Інтегра- } \\
\text { льний } \\
\text { ризик, } R\end{array}$ \\
\hline \multirow{3}{*}{1} & \multirow{3}{*}{$\begin{array}{l}\text { Електрогазозварник, } \\
\text { механічні майстерні } \\
\text { (приміщення) }\end{array}$} & \multirow{3}{*}{3.1} & $\begin{array}{c}\text { Шкідливі хімічні } \\
\text { речовини } \\
\text { (марганець) } \\
\end{array}$ & 0,2 & 0,31 & 0,02164 & \multirow{3}{*}{0,204081} \\
\hline & & & $\begin{array}{c}\begin{array}{c}\text { Пил фіброгенної дії } \\
\text { (заліза оксид) }\end{array} \\
\end{array}$ & 6 & 6,5 & 0,004434 & \\
\hline & & & $\begin{array}{c}\text { Інфрачервоне ви- } \\
\text { промінювання, } \\
\text { Вт/м }{ }^{2}\end{array}$ & до 140 & 223 & 0,182853 & \\
\hline \multirow{3}{*}{2} & \multirow{3}{*}{$\begin{array}{l}\text { Електрогазозварник, } \\
\text { механічні майстерні } \\
\text { (вулиця) }\end{array}$} & \multirow{3}{*}{3.1} & $\begin{array}{c}\text { Шкідливі хімічні } \\
\text { речовини, } \\
\text { марганець } \\
\end{array}$ & 0,2 & 0,33 & 0,024727 & \multirow{3}{*}{0,223607} \\
\hline & & & $\begin{array}{c}\text { Пил фіброгенної дії, } \\
\text { заліза оксид } \\
\end{array}$ & 6 & 6,3 & 0,002703 & \\
\hline & & & $\begin{array}{c}\text { Інфрачервоне ви- } \\
\text { промінювання, } \\
\text { Вт/м } \text { м }^{2} \\
\end{array}$ & до 140 & 234 & 0,201765 & \\
\hline 3 & $\begin{array}{l}\text { Машиніст незнімної } \\
\text { дрезини АГД 1А, } \\
\text { механічні майстерні }\end{array}$ & 3.2 & Шум, дБА & 80 & 83 & 0,000609 & 0,000609 \\
\hline \multirow[b]{2}{*}{4} & \multirow{2}{*}{$\begin{array}{l}\text { Коваль ручного кування, } \\
\text { цех механічних майсте- } \\
\text { рень, кузня }\end{array}$} & \multirow[b]{2}{*}{3.3} & Шум, дБА & 75 & 92 & 0,003373 & \multirow[b]{2}{*}{0,326984} \\
\hline & & & $\begin{array}{c}\text { Інфрачервоне ви- } \\
\text { промінювання, } \\
\text { Вт/м }{ }^{2} \\
\end{array}$ & до 140 & 320 & 0,324706 & \\
\hline \multirow{2}{*}{5} & \multirow{2}{*}{$\begin{array}{l}\text { Тракторист, механічні } \\
\text { майстерні }\end{array}$} & \multirow{2}{*}{3.2} & Пил фіброгенної дії & 4 & 4,3 & 0,003834 & \multirow{2}{*}{0,005402} \\
\hline & & & Шум, дБА & 80 & 88 & 0,001574 & \\
\hline 6 & $\begin{array}{l}\text { Машиніст залізнично-бу- } \\
\text { дівельної машини ПМГ, } \\
\text { механічні майстерні }\end{array}$ & 3.2 & Шум, дБА & 80 & 85 & 0,001001 & 0,001001 \\
\hline
\end{tabular}

Також відомо, що доза є інтегральною величиною і визначається з урахуванням часу дії. Отримані залежності при застосуванні для атестації робочих місць значно полегшать оцінку факторів виробничого середовища і трудового процесу. Також, із урахуванням взаємного впливу факторів можна визначити пріоритетність заходів з охорони праці з урахуванням рівня виробничого і професійного ризиків, уточнення рекомендацій щодо покращення умов праці.

На основі алгоритму перетворення параметрів середовища в показник виробничого ризику був проведений аналіз карт умов праці за результатами атестації робочих місць регіональної філії «Південна залізниця» ПАТ «Українська залізниця». Отримані дані наведені у табл. 2.

Проведена оцінка умов праці свідчить про те, що робочі місця № 1, № 2, № 4 відносяться до 3.1 класу згідно [5], але показники інтегрального ризику згідно [4] є надмірними. Робочі місця № 3, № 5, № 6 відносяться до 3.2 класу, маючи за розрахунками показники інтегрального ризику $10^{-4}, 10^{-3}$ i $10^{-3}$ відповідно, тобто гранично - допустимими і вище [4]. Отже, маємо доведену суб єктивність оцінки фактичних умов та характеру праці згідно [5]. Показники інтегрального ризику свідчать про протиріччя українського законодавства зі світовими нормами щодо охорони здоров`я та безпеки праці для створення контрольованих умов, які мінімізують можливі наслідки шкідливих та небезпечних факторів виробничого середовища та трудового процесу [3].

Хоча такий підхід не можна визначити як абсолютно вірний тому, що не має врахування імовірності перебування працюючого у зоні дії $i$-го небезпечного фактору. Враховуючи це, імовірність наявності $i$-го небезпечного фактору в робочій зоні можна визначити за такою формулою: 


$$
P_{v_{i}}=P_{i}^{v} \cdot P_{i}^{p},
$$

де $P_{i}^{v}$ - імовірність дії $i$-го небезпечного фактору; $P_{i}^{p}-$ імовірність перебування працюючого у зоні дії $i$-го небезпечного фактору.

Також, імовірність дії $i$-го небезпечного фактору та імовірність перебування працюючого у зоні його дії визначається за формулами:

$$
\begin{aligned}
& P_{i}^{v}=t_{i}^{v} / T_{C M} ; \\
& P_{i}^{p}=t_{i}^{p} / T_{C M},
\end{aligned}
$$

де $t_{i}^{v}$ - час дії $i$-го небезпечного фактору; $t_{i}^{p}$ - час перебування працюючого у зоні дії $i$-го небезпечного фактору; $T_{C M}$ - тривалість зміни.

Підставляючи дані вирази у формулу (10), отримуємо імовірність дії $i$-го небезпечного фактору на працюючого:

$$
P_{v_{i}}=\frac{1}{T_{C M}^{2}}\left(t_{i}^{v} \cdot t_{i}^{p}\right) .
$$

При наявності 2, 3, ... n шкідливих факторів, імовірність їх дії визначається наступним чином:

$$
\begin{aligned}
& P_{v}(2)=P_{v_{2}}+P_{v_{1}}-P_{v_{2}} \cdot P_{v_{1}} ; \\
& P_{v}(3)=P_{v_{3}}+P_{v_{2}}-P_{v_{3}} \cdot P_{v_{2}} ; \\
& P_{v}(n)=P_{v_{n}}+P_{v_{n-1}}-P_{v_{n}} \cdot P_{v_{n-1}} .
\end{aligned} .
$$

На рис. 1 наведена залежність імовірності дії на працюючого $n$ шкідливих факторів.

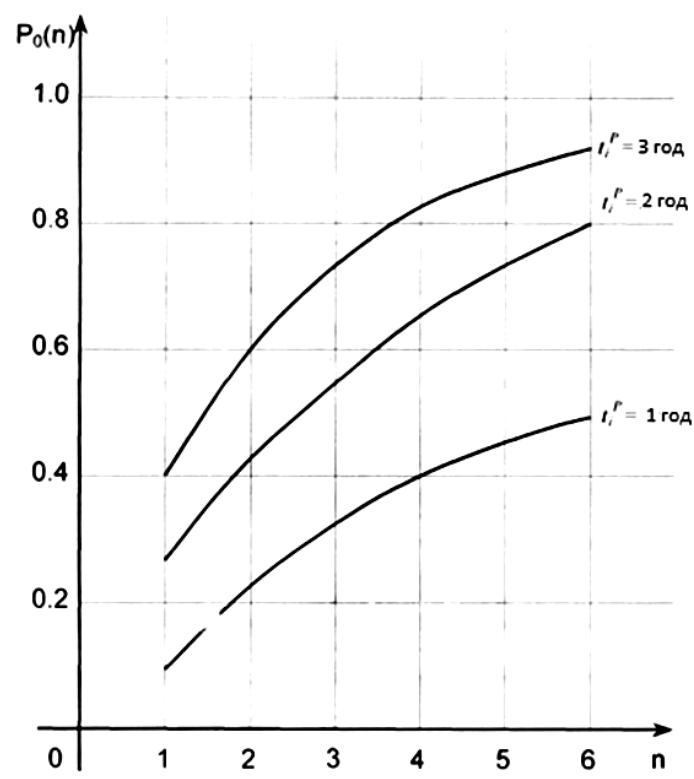

Рис. 1. Залежність $P_{0}(n)$ дії $i$-ої чисельності шкідливих факторів при $t_{j}^{p}=$ const .

За умови, що відома імовірність дії шкідливих факторів на працюючих, то визначення шкідливості виробничого процесу в цілому відбуватиметься наступним чином:

$$
P_{n n}^{0}=\frac{N_{1} P_{0}(1)+N_{2} P_{0}(2)+\ldots+N_{n} P_{0}(n)}{N},
$$

де $N_{1}, N_{2}, \ldots N_{n}$ - кількість працюючих, які підпадають під дію $1,2,3, \ldots \mathrm{n}$ шкідливих факторів; $P_{0}(1), P_{0}(2), \ldots P_{0}(n)$ - імовірність дії на працюючих $1,2,3, \ldots$ n шкідливих факторів; $N$ - загальна чисельність працюючих.

Отже, можна розрахувати шкідливість виробничого процесу в цілому для виробничого підрозділу регіональної філії «Південна залізниця»:

$$
P_{n n}^{0}=\frac{\left(\begin{array}{c}
0,96075+0,972244+0,732736+ \\
+0,80067+0,751262+0,2809
\end{array}\right)}{6}=
$$

Імовірність дії $j$-го небезпечного фактору може бути визначена за формулою:

$$
P_{b_{j}}=P_{j}^{b} \cdot P_{j}^{p} \cdot P_{j}^{n c},
$$

де $P_{j}^{b}$ - імовірність наявності у робочій зоні $j$-го небезпечного фактору (речовини); $P_{j}^{p}$ - імовірність перебування людини у зоні дії $j$-го небезпечного фактору(речовини); $P_{j}^{n c}-$ вражаюча здатність $j$-го небезпечного фактору (речовини).

Імовірність наявності у робочій зоні $j$-го небезпечного фактору (речовини) та імовірність перебування людини у зоні дії цього фактору визначається за формулою (11). А вражаюча здатність $j$-го небезпечного фактору (речовини) визначається як:

$$
P_{j}^{n c}=\frac{d_{j}}{D_{j}},
$$

$d_{j}$ - фактичний рівень (вміст) $j$-го небезпечного фактору (речовини); $D_{j}-$ граничний рівень (вміст) $j$-го небезпечного фактору (речовини).

Граничний рівень (вміст) $j$-го небезпечного фактору (речовини) - це такий, при якому працюючі підлягають найшвидшій евакуації 3 небезпечної зони.

Якщо підставити у формулу (16) вирази для $P_{j}^{b}$, $P_{j}^{p}$ і $P_{j}^{n c}$, отримаємо:

$$
P_{b_{j}}=\frac{t_{j}^{b} \cdot t_{j}^{p} \cdot d_{j}}{T_{C M}^{2} \cdot D_{j}} .
$$

Імовірність шкідливої дії $m$ факторів визначається за формулою:

$$
P_{b}(m)=1-\prod_{j=1}^{m}\left(1-P_{b_{j}}\right) .
$$

На рис 2 наведена залежність можливості дії на людину $m$ шкідливих факторів.

Якщо відома імовірність дії шкідливих факторів на працюючих, то можна визначити шкідливість виробничого процесу в цілому:

$$
P_{n n}^{b}=\frac{N_{1} P_{b}(1)+N_{2} P_{b}(2)+\ldots+N_{m} P_{b}(m)}{N},
$$




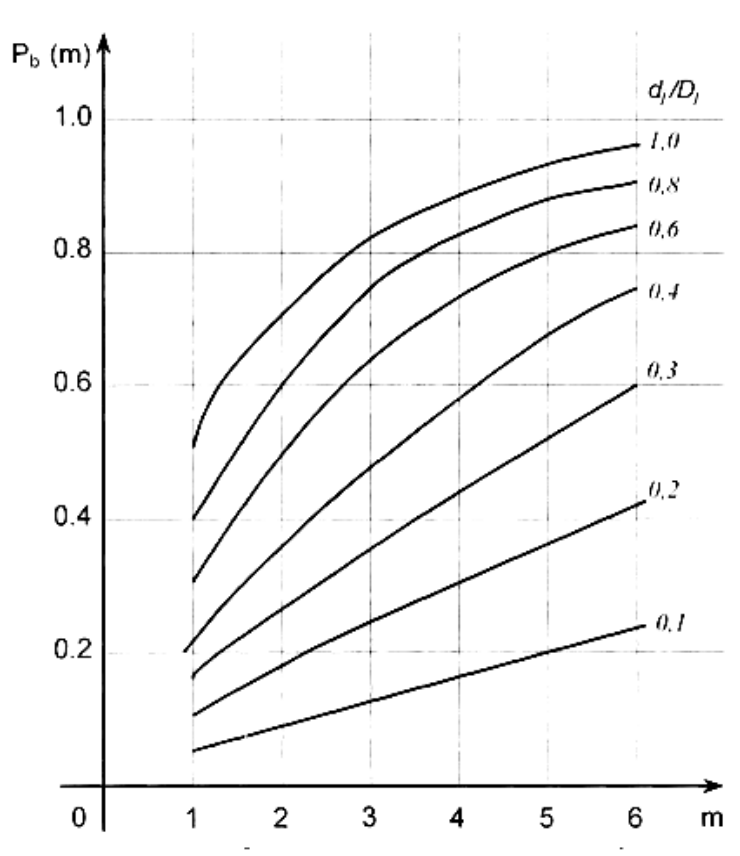

Рис. 2. Залежність $P_{b}(m)$

від $m$-ої кількості шкідливих факторів та $d_{j} / D_{j}\left(t_{j}^{b} \mathrm{i} t_{j}^{p}=\right.$ const $)$
Результати проведених розрахунків кількісної оцінки потенційної шкідливості виробничих процесів на базі даних оцінки факторів виробничого середовища і трудового процесу з карт умов праці регіональної філії «Південна залізниця» ПАТ «Українська залізниця» приведені у табл. 3:

$$
\begin{gathered}
P_{n n}^{b}= \\
=\frac{\left(\begin{array}{c}
0,294519+0,326391+0,467824+ \\
+0,294519+0,339346+0,183665
\end{array}\right)}{6}=
\end{gathered}
$$$$
=0,317711 \text {. }
$$

Привертає до себе увагу той факт, що умови праці машиніста залізнично-будівельної машини ПМГ, які характеризуються інтегральним ризиком $1 \cdot 10^{-3}$ і умови праці тракториста, які характеризуються інтегральним ризиком $5,4 \cdot 10^{-3}$ відповідно до [5], визначені як шкідливі за класом 3.2, а умови праці електрогазозварників, які характеризуються інтегральним ризиком $2,04 \cdot 10^{-1}$ i $2,23 \cdot 10^{-1}$ як шкідливі по класу 3.1.

Таблиця 3 - Кількісна оцінка потенційної шкідливості виробничих процесів

\begin{tabular}{|c|l|c|c|c|}
\hline $\begin{array}{c}\text { № } \\
\text { 3/п }\end{array}$ & $\begin{array}{l}\text { Робоче місце, } \\
\text { професія, } \\
\text { цех } \\
\text { (дільниця, відділ) }\end{array}$ & $\begin{array}{c}\text { Імовірність дії на } \\
\text { працюючого } \boldsymbol{n} \text { шкід- } \\
\text { ливих факторів, } P_{v_{i}}\end{array}$ & $\begin{array}{c}\text { Імовірність дії } \boldsymbol{j} \text {-го } \\
\text { небезпечного факто- } \\
\text { ру, } P_{b_{j}}\end{array}$ & $\begin{array}{c}\text { Інтеграль- } \\
\text { ний } \\
\text { ризик, } \boldsymbol{R}\end{array}$ \\
\hline 1 & $\begin{array}{l}\text { Електрогазозварник, } \\
\text { механічні майстерні (приміщення) } 3.1\end{array}$ & 0,96075 & 0,294519 & 0,204081 \\
\hline 2 & $\begin{array}{l}\text { Електрогазозварник,3.1 } \\
\text { механічні майстерні (вулиця) }\end{array}$ & 0,972244 & 0,326391 & 0,223607 \\
\hline 3 & $\begin{array}{l}\text { Машиніст незнімної дрезини АГД 1А, } \\
\text { механічні майстерні 3.2 }\end{array}$ & 0,732736 & 0,467824 & 0,000609 \\
\hline 4 & $\begin{array}{l}\text { Коваль ручного кування, цех механіч- } \\
\text { них майстерень, кузня 3.3 }\end{array}$ & 0,80067 & 0,294519 & 0,326984 \\
\hline 5 & Тракторист, механічні майстерні 3.2 & 0,751262 & 0,339346 & 0,005402 \\
\hline 6 & $\begin{array}{l}\text { Машиніст залізнично-будівельної } \\
\text { машини ПМГ, механічні майстерні 3.2 }\end{array}$ & 0,2809 & 0,183665 & 0,00101 \\
\hline
\end{tabular}

Аналіз отриманих даних свідчить, що націленість законодавців на усунення шкідливих або небезпечних факторів виробничого середовища і трудового процесу є поверховою, а також про суб єктивність [5] в частині визначення шкідливості виробничого процесу в цілому. На основі проведених розрахунків доведено необхідність перегляду [5] на відповідність світовим нормам охорони здоров'я та безпеки праці щодо створення контрольованих умов, які мінімізують можливі наслідки шкідливих та небезпечних факторів виробничого середовища та трудового процесу.

Даний підхід доцільно застосовувати у топографічному методі аналізу виробничого травматизму, який полягає у вивченні причин нещасних випадків щодо місця їхнього виникнення. Але метод дає загальну картину стану травматизму за даними про випадки, які вже сталися.
Ризик-орієнтований підхід дасть змогу на стадії імовірності виникнення попередити нещасні випадки $з$ більшою точністю через виявлення в процесі дослідження імовірних місць зосередження травматизму.

Отже, підтверджено експериментально реальність зниження динаміки виробничого травматизму на етапі усунення вже існуючих залежностей.

\section{Висновки}

Отримано єдиний підхід до розрахунку виробничого ризику в залежності від параметрів робочої зони з урахуванням часу перебування працюючих у зоні дії небезпечних факторів, який не потребує введення множини шкал для характеристики якості середовища. Отримані на основі ризик-орієнтованого підходу залежності можна застосовувати для атестації робочих місць, при визначенні пріоритету 
щодо заходів 3 охорони праці 3 урахуванням рівня виробничого і професійного ризиків.

Призначення системи менеджменту охорони здоров'я та безпеки праці полягає в тому, щоб забезпечити середовище для управління запобіганням смертельних випадків, професійних травм i шкоди для здоров'я, удосконалювати і забезпе- чувати безпечні і здорові умови праці для своїх працівників та інших осіб, які працюють під контролем організації.

Отже, визначення небезпек і ризиків в області охорони здоров`я та безпеки праці, пов'язаних 3 діяльністю організації $є$ пріоритетним завданням для інтеграції у світове співтовариство.

\section{СПИСОК ЛІТЕРАТУРИ}

1. Human Health Risk Assessment Toolkit: Chemical Hazards. Harmonization Project Document. IPCS, WHO, 2010. № 8. 105 p. URL: https://apps.who.int/iris/handle/10665/44458 (last access: 7.12.2019).

2. Consumer Health and Food Safety. COM (97) 183 final. Communication of the EU, 1997. 35 p. URL: https://ec.europa.eu/commission/presscorner/detail/en/IP_97_508 (last access: 7.12.2019).

3. ISO 45001 Системи менеджменту охорони здоров 'я i безпеки праці. Вимоги 3 застосування. URL: ttps://www.iso.org/standard/63787.html (дата звернення 3.12.2019).

4. ISO 31000 Risk management. Principles and guidelines. URL: https://risk-engineering.org/ISO-31000-risk-management/ (last access: 4.12.2019).

5. Про затвердження Державних санітарних норм та правил «Гігієнічна класифікація праці за показниками шкідливості та небезпечності факторів виробничого середовища, важкості та напруженості трудового процесу» / Наказ МО3 України № 248 від 08 квіт. 2014 p. URL: https://zakon2.rada.gov.ua/laws/show/z0472-14 (дата звернення 2.12.2019).

6. Про охорону праці: Закон України від 18 лист. 2012 p. URL: http://zakon4.rada.gov.ua/laws/show/2694-12 (дата 3вернення 27.11.2019).

7. Гогунский, В.Д. Чернега Ю.С. Управління ризиками в проектах з охорони праці як метод усунення шкідливих $\mathrm{i}$ небезпечних умов праці. Вост.-Европейский журнал передовых технологий. 2013. № 1/10 (61). С. 83-85.

8. Гогунский, В.Д., Руденко С.В., Урядникова И.В.Теория и практика оценки риска здоровью от воздействия факторов внешней среды. Безпека життя і діяльності людини - освіта, наука, практика : зб. наук. пр. Х міжнар. наук.-метод. конф. Київ : Центр учбової літератури, 2011. С. 170-175.

9. ДСТУ ISO 14001:2006. Системи екологічного керування. Вимоги та настанови щодо застосування (ISO 14001:2004, IDT). [Чинний від 2016-07-01]. Київ, 2006. 17 с. (Держспоживстандарт України).

10. Басиль Е.Е., Изотов С.А., Гогунский В.Д. Риск сокращения продолжительности жизни: рабочая зона. Tpyды Oдесского политехнического университета. 1997. Вып. 2. С.133-135.

11. Руденко, С.В., Гогунский В.Д. Оценка экологической безопасности в проектах: монографія. Одесса : Феникс, 2006. $144 \mathrm{c}$.

12. Оцінка ризику для здоров'я населення від забруднення атмосферного повітря: методичні рекомендації. URL: http://ua-info.biz/legal/baseuw/ua-qmwote/index.htm (дата звернення 2.12.2019).

13. Гогунский, В.Д. Олех Т.М., Оборская А.Г. Практические задачи измерения качества в проектах. Вост.-Европейский журнал передовых технологий. 2012. №1/11 (55). С. 6-8.

Received (Надійшла) 28.11.2019

Accepted for publication (Прийнята до друку) 29.01.2020

\section{A risk-oriented approach to determining working conditions of certain categories of the workers in transport industry}

\section{O. Tretyakov, B. Harmash, B. Khalmuradov, Ye. Biletska}

Abstract. This article discusses the analysis of the principles, methods and criteria of risk assessment. The definition has been given to the concept of professional risk as harm to human health by the conditions of professional activity. It has been established that the main direction of improving the safety of working conditions is a systematic approach based on the analysis and assessment of risks caused by the specifics of processes in the transport industry. Objective regularities of the occurrence of hazards in the professional activities of railway workers have been identified. The current trend of globalization of the world economy and regional integration has increased the need for cooperation between countries, since objectively there are common goals and approaches in the field of industrial safety and occupational health, the need for interaction between occupational safety and environmental changes, as well as between occupational health and productivity. The purpose of such a systematic policy is to prevent accidents and occupational diseases of workers as a result of dangerous situations and transport accidents. A unified approach to calculating production risk depending on the parameters of the working area has been obtained, taking into account the time spent by hazardous factors working in the affected area, which does not require entering multiple scales to characterize the quality of the environment. Based on the algorithm for converting environmental parameters into an production risk indicator, an analysis of working conditions maps was carried out according to the results of certification of jobs at the regional branch of Southern Railway, PJSC Ukrainian Railway. The obtained integral risk indicators show the subjectivity of the assessment of actual conditions and the nature of labor in accordance with the existing legislation. The contradiction between the Ukrainian legislation and the world standards for the protection of labor health and safety for controlled conditions that minimize the possible consequences of harmful and dangerous factors in the working environment and the labor process has been revealed. A method is proposed for determining the danger level for workers in the working area under the conditions of the joint action of harmful factors of various classes. The method provides that the dependencies obtained on the basis of the risk-based approach can be used to certify jobs when determining the priority of labor protection measures taking into account the level of production and occupational risks.

Keywords : transport, professional risk, industrial hazard, harmful factor, unsafety factor, occupational safety and health, labor protection, hygiene standards. 